\title{
Nicholas Breton
}

\section{$1545 ?-1626$}

Nicholas Breton was born into an eminent family in Essex; his father died when he was young, and his mother then married the poet George Gascoigne. Details of Breton's life are obscure, but he was probably educated at Oriel College, Oxford, after which he settled in London as a writer. His publications include twenty-two volumes of poetry, twenty-two books in prose, and various poems in anthologies. $\mathrm{He}$ wrote satire, romance and religious verse, but his finest poems are pastoral lyrics.

\section{SHALL WE GO DANCE THE HAY}

Shall we go dance the hay, ${ }^{\dagger}$ the hay?

Never pipe could ever play

Better shepherd's roundelay. ${ }^{\dagger}$

Shall we go sing the song, the song?

5 Never love did ever wrong,

Fair maids, hold hands all along.

Shall we go learn to woo, to woo?

Never thought came ever to,

Better dead could better do.

10 Shall we go learn to kiss, to kiss?

Never heart could ever miss

Comfort, where true meaning is.

Thus at base ${ }^{\dagger}$ they run, they run, When the sport was scarce begun.

15 But I waked, and all was done.

1600

hay a country dance with a serpentine 